\title{
Peningkatan Hasil Belajar IPA Melalui Pendekatan Scientific Terintegrasi dengan Multimedia Interaktif pada Peserta Didik Kelas VI SD Negeri 10 Singkawang Utara
}

\author{
Arnold Jacobus ${ }^{1)}$ \\ 1) Sekolah Dasar Negeri 90 Singkawang, Indonesia \\ E-mail: arnold.jacobus@yahoo.com
}

\begin{abstract}
Abstrak. Salah satu permasalahan yang dialami peserta didik kelas VI SD Negeri 10 Singkawang Utara dalam pembelajaran IPA adalah kurang aktifnya peserta didik dalam proses pembelajaran dan nilai peserta didik selalu rendah. Alternatif yang dipilih untuk mengatasi masalah tersebut adalah melalui pendekatan scientific terintegrasi dengan multimedia interaktif. Penelitian dilakukan melalui penelitian tindakan kelas (PTK). Dengan pendekatan pembelajaran tersebut, peserta didik dapat terlibat aktif mengikuti pembelajaran yang berdampak pada peningkatan hasil belajarnya. Hasil penelitian menunjukkan peningkatan hasil belajar dari prasiklus dengan nilai rata-rata 63 meningkat 78 pada siklus I dan meningkat lagi menjadi 96 pada siklus II.
\end{abstract}

Kata kunci: pendekatan scientific, multimedia interaktif, hasil belajar IPA

\section{Pendahuluan}

Imu Pengetahuan Alam (IPA) diperlukan dalam kehidupan sehari-hari untuk memenuhi kebutuhan manusia melalui pemecahan masalah-masalah yang dapat diidentifikasi. IPA adalah pengetahuan yang sistematis dan disusun dengan menghubungkan gejala-gejala alam yang bersifat kebendaan dan didasarkan pada hasil pengamatan. Oleh karena itu, proses pembelajaran IPA di sekolah khususnya tingkat SD lebih menekankan pada pelaksanaan ilmiah (scientific) untuk menumbuhkan kemampuan berpikir, bekerja dan bersikap ilmiah serta mengkomunikasikannya sebagai aspek penting kecakapan hidup.

Salah satu pendekatan yang digunakan dalam pembelajaran IPA adalah pendekatan proses. Ada beberapa macam pendekatan yang biasa digunakan dalam pembelajaran IPA, yaitu pendekatan yang menekankan pada fakta, konsep dan proses [1]. Pendekatan proses didasarkan atas kegiatan yang bisa dilakukan oleh para ilmuwan dalam pengembangan ilmu pengetahuan. Keterampilan ilmiah yang dimiliki para ilmuwan dalam membangun atau membuktikan suatu teori, yaitu keterampilan mengobservasi, mengklasifikasi, mengukur, mengkomunikasikan, menginferensi, memprediksi, mengenal hubungan ruang dan waktu, serta mengenal hubungan-hubungan angka.

Belajar IPA merupakan proses aktif. Belajar IPA merupakan sesuatu yang harus dilakukan oleh peserta didik, bukan sesuatu yang dilakukan untuk peserta [2]. Dalam belajar IPA, peserta didik mempertanyakan, menjelaskan obyek dan peristiwa, mengajukan pertanyaan, memperoleh pengetahuan, menyusun penjelasan tentang gejala alam, menguji penjelasan tersebut dengan cara-cara yang berbeda, dan mengkomunikasikan gagasan pada pihak lain.
Pembelajaran IPA di kelas VI SD Negeri 10 Singkawang Utara yang dilakukan masih belum menggunakan tahapan-tahapan ilmiah yang disusun secara sistematis seperti yang dilakukan oleh para ilmuwan. Pada pembelajaran IPA khususnya materi ciri-ciri planet, terkadang proses ilmiah hanya dilakukan satu tahap, contohnya hanya melakukan pengamatan gambar-gambar planet, atau hanya melakukan percobaan/eksperimen terhadap alat peraga planet. Ini berdampak pada informasi yang seharusnya bisa dikuasai peserta didik seutuhnya, namun hanya bisa diserap sedikit oleh peserta didik. Hal ini berdampak pula pada hasil belajarnya yang belum memuaskan. Dari hasil tes yang diberikan pada materi ciriciri planet, yaitu ketika peserta didik diminta untuk menyebutkan ciri-ciri dari beberapa planet yang ada dalam tata surya, hanya didapat nilai rata-rata 63 (KKM 65) dan hanya $32 \%$ peserta didik yang mendapatkan nilai di atas KKM (Kriteria Ketuntasan Minimal).

Salah satu cara untuk mengatasi permasalahan yang dihadapi tersebut adalah dengan menerapkan pendekatan keterampilan proses. Dalam kurikulum 2013, Pemerintah telah menjelaskan bahwa pembelajaran harus menekankan pada dimensi pedagogik modern, yaitu menggunakan pendekatan ilmiah. Pendekatan ilmiah (scientific approach) atau scientific terintegrasi dalam pembelajaran meliputi kegiatan mengamati, menanya, mengumpulkan informasi/mencoba, mengasosiasi/menalar/mengolah informasi, serta menyajikan/mengkomunikasikan [3].

Selain pembelajaran dilaksanakan dengan pendekatan scientific terintegrasi, proses pembelajaran juga menggunakan media pembelajaran multimedia interaktif yang berupa aplikasi susunan tata surya dan alat peraga sistem tata surya. Karena penggunaan alat peraga IPA sangat 
dibutuhkan dalam pembelajaran IPA yang menerapkan pendekatan keterampilan proses, agar pembelajaran menjadi lebih bermakna bagi peserta didik [4]. Pembelajaran dengan menggunakan alat peraga akan dapat memperbesar perhatian peserta didik terhadap pembelajaran yang dilangsungkan, karena mereka terlibat aktif dalam pembelajaran yang dilaksanakan. Materi ciri-ciri planet adalah suatu materi yang abstrak dan jauh dari jangkauan indera peserta didik. Jadi, untuk menyampaikan materi tersebut diperlukan alat bantu berupa multimedia interaktif tentang tata surya. Dengan bantuan media pembelajaran, konsentrasi belajar dapat lebih ditingkatkan.

Berdasarkan masalah sebagaimana tertuang di atas, maka guru mengambil tindakan berupa rencana untuk melakukan perbaikan pembelajaran, agar dapat memperbaiki hasil belajar peserta didik yang semula sangat rendah dapat menjadi lebih baik. Adapun hal-hal yang menjadi tujuan penelitian adalah peningkatan aktifitas belajar dan hasil belajar peserta didik dalam pembelajaran IPA.

\section{METODE}

Metode dalam penelitian ini adalah PTK (Penelitian Tindakan Kelas). Penelitian dilaksanakan dengan menggunakan empat tahap kegiatan, yaitu merencanakan, melakukan tindakan, pengamatan (pengolahan data), dan refleksi [5].

Data diperoleh melalui lembar observasi aktifitas peserta didik dalam kegiatan scientific terintegrasi dan tes individu serta tugas kelompok. Pengamatan aktifitas peserta didik dilakukan oleh teman sejawat dengan bantuan alat rekam (kamera digital).

Peneliti melaksanakan pembelajaran sesuai dengan skenario pembelajaran yang disusun bersama teman sejawat yaitu pembelajaran IPA yang mengutamakan pendekatan scientific terintegrasi dengan penggunaan multimedia interaktif. Adapun tahap perencanaan yang dibuat adalah sebagai berikut: (1)menyusun skenario pembelajaran perbaikan pembelajaran (RPP perbaikan), (2)membuat lembar kerja kelompok (eksperimen), (3)menyusun instrumen pengamatan/penilaian (rubrik penilaian hasil kerja peserta didik, lembar pengamatan aktifitas peserta didik dalam tahap scientific terintegrasi), (4)menentukan teman sejawat (rekan guru), (5)menyiapkan media pembelajaran (multimedia interaktif dan alat peraga), (6)menentukan indikator keberhasilan (85\% peserta didik mencapai KKM), (7)menentukan jadwal pelaksanaan perbaikan pembelajaran.

Multimedia interaktif yang digunakan adalah video animasi yang berisi gambar planet-planet dalam tata surya beserta ciri-cirinya. Anak diberi keleluasaan menggali informasi-informasi yang penting dalam multimedia (membaca dan mendengarkan video interaktif). Diharapkan dengan adanya multimedia ini, anak dapat mengumpulkan informasi-informasi yang berkaitan dengan materi pelajaran, karena salah satu kecakapan ilmiah adalah dapat mengumpulkan informasi dari berbagai sumber.

Subyek penelitian adalah peserta didik di kelas VI SD Negeri 10 Singkawang Utara yang berjumlah 37 orang, terdiri dari 16 orang laki-laki dan 21 orang perempuan. Peserta didik pada kelas tersebut mayoritas dari keluarga petani dan nelayan, yang tingkat pendidikan orang tuanya setingkat SD dan SMP.

\section{A. Siklus I}

Perbaikan pembelajaran siklus I dilaksanakan hari selasa tanggal 14 dan 16 April 2015 pada jam pelajaran ke 1-3. Tindakan perbaikan pembelajaran dilaksanakan sesuai skenario yang telah disusun penulis bersama teman sejawat (RPP Siklus I). Pada kegiatan awal guru membuka pembelajaran dengan mengucapkan salam, kemudian dilanjutkan dengan apersepsi yaitu bertanya kepada peserta didik tentang keadaan langit pada malam dan siang hari. Guru mengajukan pertanyaan awal "Anak-anak, apa yang kalian lihat di langit tadi malam?". "ada bulan dan bintang pak!" jawab peserta didik. Guru bertanya lagi" bagus, coba sekarang lihat kelangit, apa yang terlihat?" peserta didik menjawab "ada matahari dan awan pak?". " bagus sekali, anak-anak!, bintang, bulan, dan matahari yang kalian sebutkan tadi adalah benda-benda yang ada di langit" guru menanggapi jawaban peserta didik.

Guru memberikan apersepsi dengan tujuan mengajak/membawa peserta didik masuk ke dalam dunia pembelajaran yang telah dirancang. Setelah itu, untuk mencairkan suasana ketegangan yang dialami sebagian anak dikarenakan kehadiran teman sejawat, maka guru mengajak anak menyanyikan sebuah lagu "Bintang Kecil" yang nadanya guru ganti dengan nada lagu perjuangan "Maju Tak Gentar" agar lebih bersemangat. Pembelajaran kemudian dilanjutkan dengan menyampaikan tujuan pembelajaran, kegiatan pembelajaran dan bentuk penilaian selama pembelajaran.

Pada kegiatan inti guru menayangkan video pembelajaran melalui media infocus. Peserta didik diminta untuk mengamati dan mencatat informasi-informasi yang penting selama pengamatan berlangsung. Setelah itu peserta didik diberi kesempatan untuk bertanya mengenai hal-hal yang muncul pada proses pengamatan. Kegiatan berikutnya peserta didik dibagi menjadi 7 kelompok, setiap kelompok berjumlah 5-6 orang dan masing-masing kelompok mendapatkan satu lembar kerja kelompok (LKK) untuk dikerjakan bersama anggota kelompoknya. Peserta didik mengerjakan LKK berdasarkan informasi-informasi yang didapat pada waktu pengamatan video dan juga informasi yang ada ketika mereka membaca buku teks. Guru terus membimbing anak selama tugas kelompok dikerjakan. Selesai tugas kelompok dikerjakan, peserta didik mewakili kelompoknya diminta untuk mempresentasikan hasil tugasnya di depan kelas secara bergantian. Kelompok yang lain bersama guru menanggapi hasil tugas kelompok yang maju di depan kelas.

Pada kegiatan akhir peserta didik dengan bantuan guru menyimpulkan materi yang telah dipelajari. Kemudian peserta didik diberikan tes individu untuk mengetahui sampai dimana tingkat penguasaan peserta didik terhadap pembelajaran yang telah dilaksanakan. Lembar tes individu 
dikumpulkan, lalu guru menutup pembelajaran dengan memberikan arahan untuk belajar lagi di rumah.

Setelah pembelajaran selesai, guru bersama teman sejawat langsung melakukan analisis aktifitas belajar peserta didik dan hasil pembelajaran yang telah dilakukan. Hasil pengamatan aktifitas belajar peserta didik didapat data, kegiatan scientific terintegrasi yang dilakukan peserta didik yaitu tahapan: mengamati, menanya, mengumpulkan informasi/mencoba, mengolah informasi/menalar, dan mengkomunikasikan sudah terlaksana dengan baik, namun belum semua peserta didik melakukan tahapan-tahapan scientific terintegrasi yang telah dirancang. Pada kegiatan mengamati hanya 25 dari 37 orang yang terlihat aktif atau hanya sebanyak $68 \%$ orang. Tahapan scientific terintegrasi yang sangat sedikit melibatkan peserta didik yaitu hanya 15 orang $(41 \%$ orang) adalah pada tahapan mengolah informasi/menalar, dimana tahapan ini dilaksanakan pada saat mengerjakan tugas kelompok. Terlihat hanya beberapa peserta didik dalam kelompok yang aktif mengerjakan lembar LKK. Sebagian besar hanya peserta didik yang pintar saja yang mengerjakan Lembar Kerja Kelompok, anggota yang lain hanya melihat temannya. Ini dikarenakan karena LKK hanya diberikan satu buah untuk masing-masing kelompok.

Hasil tugas kelompok dan tes akhir pembelajaran yang dilaksanakan untuk mengetahui tingkat pemahaman peserta didik, data tersebut didapat dari rata-rata hasil nilai portofolio (tugas kelompok) dengan perolehan nilai individu. Perolehan nilai diantara 65-74 sebanyak 10 orang, dan perolehan nilai $\geq 95$ diraih oleh 4 orang. Pada siklus I ini terlihat adanya peningkatan hasil belajar peserta didik dibanding nilai sebelum perbaikan pembelajaran, yaitu sebanyak 30 peserta didik mendapat nilai $\geq 65$. Namun hasil ini belum memuaskan, karena ketuntasan klasikal belum tercapai sesuai dengan tujuan perbaikan yaitu lebih dari $85 \%$ peserta didik mendapat nilai di atas KKM $(\geq 65)$. Ketuntasan klasikal hanya mencapai $81 \%$ (30 orang). Oleh karena itu, penelitian akan dilanjutkan pada siklus II.

\section{B. Siklus II}

Perbaikan pembelajaran siklus II dilaksanakan hari selasa tanggal 21 dan 23 April 2015 pada jam pelajaran ke 1-3. Tindakan perbaikan pembelajaran dilaksanakan sesuai skenario yang telah disusun penulis bersama teman sejawat (RPP Siklus II). Pada kegiatan awal guru membuka pembelajaran dengan mengucapkan salam, kemudian dilanjutkan dengan appersepsi yaitu bertanya kepada peserta didik tentang jumlah planet dalam tata surya. Guru bertanya, "Anak-anak, ada berapa planet dalam sistem tata surya kita ?", "8 pakkkk..... !", jawab anak kompak. Guru bertanya lagi, " bagus, coba kalian sebutkan planet apa saja?," salah satu peserta didik yang bernama Agnil mengangkat tangan dan menjawab " Merkurius, Venus, Bumi, Mars, Jupiter, Saturnus, Uranus, Neptunus!.” bagus sekali, kamu anak pintar Agnil!, Guru menanggapi jawaban salah satu peserta didik.

Guru memberikan apersepsi dengan tujuan mengajak/membawa peserta didik masuk kedalam dunia pembelajaran yang telah dirancang. Setelah itu, untuk mencairkan suasana ketegangan yang dialami sebagian anak dikarenakan kehadiran teman sejawat, maka guru mengajak peserta didik menyanyikan sebuah lagu yang berjudul "Bintang Kejora", dengan diiringi lagu aslinya yang diputar guru melalui infocus. Pembelajaran kemudian dilanjutkan dengan menyampaikan tujuan pembelajaran, bentuk kegiatan pembelajaran scientific terintegrasi dan bentuk penilaian selama pembelajaran.

Setelah itu peserta didik diajak keluar kelas untuk melakukan simulasi revolusi planet terhadap matahari. Ada 9 orang peserta didik yang berperan sebagai matahari dan planet-planet. Peserta didik yang menjadi matahari berdiri diam di tengah lapangan, dan 8 orang lainnya yang menjadi planet mengelilingi matahari tersebut. Peserta didik yang tidak mendapat peran dalam simulasi, bertugas untuk mengamati dan mencatat hasil pengamatannya ke dalam buku. Percobaan ini bertujuan untuk membuktikan bahwa jarak planet dengan matahari berpengaruh terhadap kala revolusi planet tersebut.

Pada kegiatan inti guru mengajak peserta didik kembali masuk ke dalam kelas dan menayangkan aplikasi multimedia pembelajaran melalui media infocus lalu menjelaskan cara penggunaannya. Setelah itu peserta didik diberi kesempatan untuk bertanya mengenai cara penggunaan multimedia pembelajaran yang akan mereka gunakan. Kegiatan berikutnya peserta didik dibagi menjadi 7 kelompok, setiap kelompok berjumlah 5-6 orang dan masing-masing kelompok mendapatkan satu laptop dan satu lembar kerja kelompok (LKK) untuk dikerjakan bersama anggota kelompoknya. Media laptop disediakan oleh guru sebanyak 5 buah dan dibawa oleh peserta didik yang memiliki laptop sebanyak 2 buah.

Peserta didik mengerjakan LKK berdasarkan informasiinformasi yang didapat pada waktu pengamatan multimedia interaktif dan juga informasi yang ada ketika mereka membaca buku teks serta pada waktu simulasi. Terlihat peserta didik asyik mencari informasi melalui multimedia interaktif dan langsung mencatatnya kedalam lembar kerja kelompok. Guru terus membimbing peserta didik selama tugas kelompok dikerjakan. Ketika guru berkeliling kelas untuk mengamati proses kerja kelompok, semua kelompok mengajukan pertanyaan yang sama, yaitu "mengapa posisi planet mars di dalam multimedia pembelajaran terletak pada urutan nomor 3 dari matahari, padahal posisi sebenarnya ada pada urutan 4 setelah bumi ?'. gurupun menyampaikan kesalahan itu kepada peserta didik. Memang sebelumnya, pada saat melakukan persiapan pelaksanaan pembelajaran, guru bersama teman sejawat telah menemukan kesalahan urutan planet-planet pada multimedia yang akan digunakan. Namun, kesalahan itu tidak disampaikan kepada peserta didik. Ini ditujukan untuk menguji ketelitian peserta didik dalam melakukan pengamatan multimedia interaktif.

Selesai tugas kelompok dikerjakan, peserta didik diajak untuk mengkomunikasikan hasil kerjanya dengan cara melakukan pameran hasil kerja kelompok. Di depan kelas disusun beberapa buah meja kelompok, dan hasil kerja kelompok diletakkan di atas meja tersebut. Kegiatan 
pameran dilakukan dengan cara 2 orang anggota kelompok menjaga hasil kerjanya, dan 3 orang temannya melakukan kunjungan terhadap meja kelompok lain untuk menanggapi hasil kerja kelompok lainnya itu. Terlihat peserta didik aktif bertanya dan menjawab pertanyaan kelompok lain. Peserta didik saling menanggapi antar kelompok karena terdapat beberapa perbedaan hasil tugas kelompoknya dengan kelompok lain.

Pada kegiatan akhir peserta didik dengan bantuan guru menyimpulkan materi yang telah dipelajari dan guru memberi penguatan terhadap materi-materi yang penting. Kemudian peserta didik diberikan tes individu untuk mengetahui sampai dimana tingkat penguasaan mereka terhadap pembelajaran yang telah dilaksanakan. Lembar tes individu dikumpulkan, lalu guru menutup pembelajaran dengan memberikan arahan untuk belajar lagi di rumah.

Setelah pembelajaran usai, guru bersama teman sejawat langsung melakukan analisis aktifitas belajar peserta didik dan hasil pembelajaran yang telah dilakukan. Dari hasil pengamatan aktifitas belajar peserta didik didapat data. Berdasarkan data tersebut, kegiatan scientific terintegrasi yang dilakukan peserta didik yaitu tahapan: mengamati, menanya, mengumpulkan informasi/mencoba, mengolah informasi/menalar, dan mengkomunikasikan sudah terlaksana dengan baik sesuai skenario yang dirancang. Pada kegiatan mengamati terlihat 35 peserta didik dari 37 orang yang aktif atau sebanyak $95 \%$ orang. Tahapan scientific terintegrasi yang sangat sedikit melibatkan peserta didik yaitu hanya 30 orang ( $81 \%$ peserta didik) adalah pada tahapan menanya dan tahap mengolah informasi/menalar, dimana tahapan ini dilaksanakan pada saat mengerjakan tugas kelompok. Namun pada tahap ini terjadi peningkatan dari siklus sebelumnya, terlihat sebagian besar peserta didik aktif melakukan tahapan mengolah informasi/menalar, hal ini dikarenakan lembar kerja kelompok diberikan kepada semua peserta didik. Mereka asyik berdiskusi dengan temannya, dan langsung mencatat ke dalam LKK masingmasing.

Hasil tugas kelompok dan tes akhir pembelajaran yang dilaksanakan untuk mengetahui tingkat pemahaman peserta didik. Data tersebut didapat dari rata-rata hasil nilai portofolio (tugas kelompok) dengan perolehan nilai tes individu. Perolehan nilai terendah yaitu diantara 75-84 sebanyak 2 peserta didik, dan perolehan nilai $\geq 95$ diraih oleh 30 orang peserta didik. Pada siklus II ini terlihat adanya peningkatan hasil belajar peserta didik dibanding nilai pada siklus I, yaitu sebanyak 37 orang atau $100 \%$ peserta didik mendapat nilai $\geq 65$. Ketuntasan klasikal telah tercapai sesuai dengan tujuan perbaikan yaitu lebih dari $85 \%$ peserta didik mendapat nilai di atas KKM $(\geq 65)$. Oleh karena itu, penelitian tindakan kelas pada siklus II ini bisa dikatakan telah berhasil.

\section{PEMBAHASAN}

\section{A. Peningkatan Aktifitas Belajar (Aktifitas Scientific Terintegrasi).}

Pendekatan pada perbaikan pembelajaran ini dilakukan melalui pendekatan scientific terintegrasi, yang sesuai dengan karakteristik pembelajaran IPA. Tahapan scientific terintegrasi yang dilakukan adalah kegiatan mengamati, menanya, mengumpulkan informasi/mencoba, mengolah informasi/menalar, dan mengkomunikasikan. Kegiatankegiatan tersebut muncul dalam proses pembelajaran sesuai dengan tahapan scientific terintegrasi yang telah dirancang guru bersama teman sejawat, yaitu: (1)mengamati, rancangan yang dibuat dan kemunculan pada proses pembelajaran yaitu: peserta didik mengamati multimedia interaktif, peserta didik mengamati alat peraga susunan planet, peserta didik membaca buku teks, peserta didik mengamati simulasi revolusi planet; (2)menanya, kemunculan pada proses pembelajaran yaitu: peserta didik bertanya tentang materi yang sulit, guru memancing peserta didik untuk bertanya, peserta didik bertanya cara mengerjakan LKK, peserta didik bertanya kepada temannya ketika mengerjakan tugas kelompok; (3)mengumpulkan informasi/eksperimen/mencoba, kemunculan pada proses pembelajaran yaitu: peserta didik mencatat informasi dari multimedia, peserta didik mencatat informasi dari buku teks, peserta didik melakukan simulasi revolusi planet, peserta didik mencoba alat peraga tentang revolusi planet; (4)mengolah informasi/mengasosiasi/menalar, kemunculan pada proses pembelajaran yaitu: peserta didik mengolah informasi yang telah dicatat dengan cara mengerjakan LKK yang diakhiri dengan menarik kesimpulan; (5)mengkomunikasikan, kemunculan pada proses pembelajaran yaitu: peserta didik melakukan pameran hasil tugas kelompok di depan kelas.

Dari data hasil pengamatan proses pembelajaran didapat peningkatan keaktifan peserta didik pada kegiatan scientific terintegrasi dari siklus I ke siklus II. Peningkatan itu dapat dilihat pada tabel dan diagram di bawah ini:

Tabel 1

Peningkatan Aktifitas Belajar Peserta didik Persiklus (Kegiatan Scientific)

\begin{tabular}{lccc}
\hline \multicolumn{1}{c}{ Kegiatan Scientific } & $\begin{array}{c}\text { Siklus I } \\
\text { (Peserta } \\
\text { didik) }\end{array}$ & $\begin{array}{c}\text { Siklus } \\
\text { II } \\
\text { (Peserta } \\
\text { didik) }\end{array}$ & Keterangan \\
\hline 1. Mengamati & 25 & 35 & $\begin{array}{c}+10 \text { Orang } \\
\text { (meningkat) }\end{array}$ \\
\hline 2. Menanya & 22 & 30 & $\begin{array}{c}\text { + } 8 \text { Orang } \\
\text { (meningkat) }\end{array}$ \\
\hline $\begin{array}{l}\text { 3. Mengumpulkan } \\
\text { Informasi/Mencoba }\end{array}$ & 20 & 34 & $\begin{array}{c}+14 \text { Orang } \\
\text { (meningkat) }\end{array}$ \\
\hline 4. Mengolah Informasi / Menalar & 15 & 30 & $\begin{array}{c}+15 \text { Orang } \\
\text { (meningkat) }\end{array}$ \\
\hline 5. Mengkomunikasikan & 18 & 32 & $\begin{array}{c}\text { + 14 Orang } \\
\text { (meningkat) }\end{array}$ \\
\hline
\end{tabular}

Data di atas dapat digambarkan dalam bentuk diagram sebagai berikut:

Gambar 1.

Diagram Kegiatan Scientific 


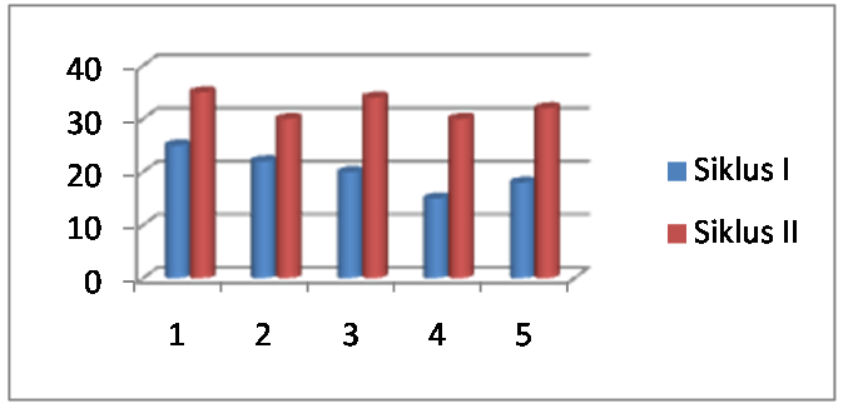

Berdasarkan tabel di atas terlihat adanya peningkatan aktifitas belajar peserta didik persiklus. Pada siklusi I aktifitas mengamati hanya dilakukan oleh 22 orang, sedangkan pada siklus II meningkat menjadi 35 orang. Ini disebabkan karena pada siklus I multimedia yang digunakan hanya diamati peserta didik melalui infocus yang ditayangkan di depan kelas, terlihat hanya beberapa peserta didik yang aktif mengamati. Sebagian besar peserta didik yang berada di barisan belakang masih pasif, karena jarak yang terlalu jauh dengan media pembelajaran. Pada siklus II guru merubah strategi dengan memberikan kepada masingmasing kelompok satu buah laptop. Peserta didik diajak untuk aktif mengamati dan mengumpulkan informasi bersama teman-temannya.

Pada tahap mengolah informasi/menalar juga terlihat peningkatan yang tinggi, yaitu dari 15 orang pada siklus I menjadi 30 orang pada siklus II. Tahap ini dirancang dengan cara mengerjakan Lembar Kerja Kelompok (LKK), yang berisi 2 buah tugas yaitu menyusun urutan planet dalam tata surya dan mengisi tabel ciri-ciri planet. Pada siklus I, LKK hanya diberikan satu lembar pada tiap kelompok, sehingga hanya beberapa peserta didik dalam kelompok yang berkesempatan mengerjakan tugas. Perbaikan dilakukan pada siklus II dengan cara memberikan LKK kepada semua peserta didik dalam kelompok, sehingga semua anggota kelompok terlibat aktif mengerjakan LKK. Strategi ini memberikan hasil yang baik karena semua peserta didik mempunyai kesempatan yang sama untuk melakukan kegiatan mengolah informasi (menalar).

\section{B. Peningkatan Hasil Belajar Peserta didik}

Hasil belajar peserta didik didapat dari tugas kelompok (portofolio) dan tes akhir yang dilakukan secara individu. Pada tugas kelompok, skor yang didapat peserta didik berdasarkan skor perolehan kelompok masing-masing. Pada akhir pembelajaran, guru juga memberikan tes individu untuk menguji sampai dimana tingkat pemahaman peserta didik terhadap materi yang telah dipelajari. Skor kelompok (portofolio) yang diperoleh peserta didik dengan skor individu dirata-ratakan menjadi skor akhir masing-masing peserta didik.

Terjadi peningkatan hasil belajar peserta didik pada tiap siklus, ini dapat dilihat pada tabel di bawah ini:

Tabel 2

Peningkatan Hasil Belajar Peserta Didik Persiklus

\begin{tabular}{cccc}
\hline Interval Nilai & $\begin{array}{c}\text { Siklus I } \\
\text { (Orang) }\end{array}$ & $\begin{array}{c}\text { Siklus II } \\
\text { (Orang) }\end{array}$ & Keterangan \\
\hline $95-100$ & 4 & 30 & +26 orang \\
\hline $85-94$ & 9 & 5 & -4 orang \\
\hline $75-84$ & 7 & 2 & -5 orang \\
\hline $65-74$ & 10 & 0 & -10 orang \\
\hline $55-64$ & 7 & 0 & -7 orang \\
\hline Jumlah & $\mathbf{3 7}$ & $\mathbf{3 7}$ & \\
\hline & & & \\
\hline
\end{tabular}

Dapat digambarkan juga melalui diagram di bawah ini:

Gambar 2.

Diagram Perolehan Hasil Belajar

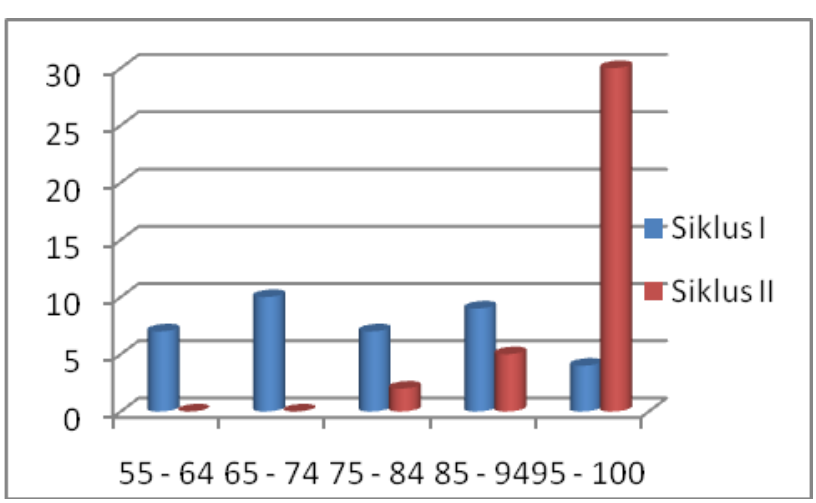

Dari data di atas, terjadi peningkatan perolehan hasil belajar peserta didik persiklus. Peningkatan terlihat signifikan pada interval nilai 95-100, pada siklus I peserta didik yang memperoleh nilai diantara 95-100 sebanyak 4 orang, kemudian meningkat pada siklus II yaitu 30 orang. Namun, pada interval nilai yang lainnya terjadi penurunan jumlah peserta didik yang memperoleh nilai tersebut. Contohnya pada perolehan nilai 65-74 terjadi penurunan dari 10 peserta didik menjadi tidak ada, ini dikarenakan peserta didik yang sebelumnya berada pada kelompok perolehan 65 74 , sekarang masuk kedalam kelompok nilai di atasnya.

Berdasarkan tujuan perbaikan pembelajaran yaitu ketuntasan belajar ditentukan sebagai berikut: (1) ketuntasan belajar individu, peserta didik mendapat nilai $\geq 65$. (2) ketuntasan klasikal, $87 \%$ anak mendapat nilai $\geq 65$. Dari tabel di atas, dapat dikatakan terjadi peningkatan ketuntasan belajar peserta didik, baik secara individu maupun klasikal. Pada siklus I ketuntasan belajar individu meningkat dari 30 menjadi 37 orang. Ketuntasan belajar klasikal juga meningkat dari $81,10 \%$ menjadi $100 \%$ peserta didik mendapatkan nilai $\geq 65$.

Hasil penelitian ini sesuai dengan apa yang dikemukan oleh Sapriati, dkk., yaitu: peranan alat peraga IPA dengan pendekatan keterampilan proses (scientific approach) antara lain dapat: (a)mengaktifkan komunikasi dan interaksi antara guru dan peserta didik dan antar sesama peserta didik dalam pembelajaran; (b)merangsang pikiran, perasaan, perhatian dan kemauan peserta didik dalam pembelajaran sehingga memberikan pengalaman belajar lebih bermakna bagi 
peserta didik; (c)membangkitkan keinginan dan minat belajar peserta didik; (d)membangun dasar-dasar untuk perkembangan belajar, sehingga membuat pelajaran lebih lama diingat; (e)memberikan pengalaman nyata yang dapat menumbuhkan kemandirian peserta didik [1].

\section{KESIMPULAN}

Berdasarkan hasil penelitian yang telah dilaksanakan penulis dan pembahasan maka dapat disimpulkan, yaitu: bahwa penerapan pendekatan scientific terintegrasi dengan multimedia interaktif dapat meningkatkan aktifitas belajar peserta didik kelas VI SD Negeri 10 Singkawang Utara dalam pembelajaran IPA materi ciri-ciri planet, sehingga berdampak pula pada peningkatan hasil belajar peserta didik.

Hendaknya dalam Pembelajaran IPA harus menekankan pada cara kerja ilmiah, yaitu dengan pendekatan scientific yang diintegrasikan dengan pemanfaatan media pembelajaran yang relevan. Penggunaan media pembelajaran dan skenario pembelajaran yang disusun secara sistematis oleh guru dapat menuntun peserta didik untuk membangun pengetahuannya sendiri, sehingga pembelajaran bermakna dapat terwujud.

\section{DAFTAR PUSTAKA}

[1] Pembelajaran IPA di SD. Jakarta: Universitas Terbuka. Sapriati A. dkk. 2008.

[2] Ragam Model dan Metode Pembelajaran IPA. Malang: PT. Pertamina (Persero) - Universitas Negeri Malang. Zubaidah, dkk. 2012.

[3] Materi Pelatihan Guru, Implementasi Kurikulum 2013. Jakarta: Kementerian Pendidikan dan Kebudayaan. Tim Penyusun Kurikulum 2013.

[4] Pendidikan IPA di SD. Jakarta: Universitas Terbuka. Nasution N.,dkk. 2002.

[5] Penelitian Tindakan Kelas. Jakarta: Universitas Terbuka Wardhani I., dkk. 2007. Wardhani I., dkk. 2007. 